\title{
Serum cystatin $C$ and cystatin C/albumin ratio for the evaluation of liver function in patients with cirrhosis.
}

\author{
Yang Xue*, Kang Changming, Li Hanhua, Qiu Chunhua \\ Department of Gastroenterology, Sichuan Academy of Medical Sciences and Sichuan Provincial People's Hospital, \\ Cheng Du, 610072, PR China
}

\begin{abstract}
Purpose: The aim of this study is to analyze the serum cystatin C (Cys C) and cystatin C/albumin (Alb) ratio in patients with cirrhosis and evaluate the role of serum $\mathrm{Cys} C$ in the evaluation of liver function. Methods: The liver function of patients was graded according to the Child-Pugh Score. According to the serum Cys $\mathrm{C}$ levels (determined with particle-enhanced immunonephelometric assay), the patients were divided into two groups: the high $\mathrm{Cys} \mathrm{C}$ level group and normal $\mathrm{Cys} \mathrm{C}$ level group. The correlation between the Child-Pugh grades/scores and the serum Cys $\mathrm{C}$ level, Cys C/Alb ratio were investigated.

Results: The Cys $\mathrm{C}$ values were not correlated to Child-Pugh grades and scores. Besides, the Cys C/Alb ratio of both groups had a linear regressive relationship with the Child-Pugh scores. Ninety-seven percentage sensitivity and $100 \%$ specificity were achieved for the evaluation of liver function in cirrhosis patients with high serum Cys $\mathrm{C}$ level.

Conclusion: Cys $\mathrm{C}$ value and $\mathrm{Cys} \mathrm{C} / \mathrm{Alb}$ ratio are accurate for liver function evaluation in the cirrhosis patients with high serum Cys $\mathrm{C}$ levels. Compared with the Cys $\mathrm{C}$ value, the Cys C/Alb ratio is more related to the liver function and can be used as an indicator in cirrhosis patients with normal serum Cys $\mathrm{C}$ level for the evaluation of liver function.
\end{abstract}

Keywords: Cystatin C, Cystatin C/albumin ratio, Cirrhosis, Child-pugh score.

Accepted on December 29, 2017

\section{Introduction}

Liver cirrhosis is a condition in which the normal liver tissue was replaced by scar tissue and formation of regenerative nodules. The gold standard for diagnosis of cirrhosis is a liver biopsy, but a biopsy is not necessary if the laboratory data suggests cirrhosis [1]. Recently, the evaluation of liver function in patients with cirrhosis has been widely studied. Compared with serum creatinine or creatinine clearance ratethe serum Cys $\mathrm{C}$ reflects the glomerular filtration rate (GFR) more accurately $[2,3]$. The Cys $\mathrm{C}$, a cysteine protease inhibitor which belongs to the super cystatin family, is a low molecular, basic and nonglycosylated protein that exists in body fluid and various cells and plays an important role in suppressing and regulating the activity of cathepsin. The serum Cys $\mathrm{C}$ can only be cleared through glomerular filtration which is independent of other influences such as gender, age and diet. Therefore, serum Cys $\mathrm{C}$ is treated as an optimal homologous marker to evaluate glomerular filtration rate. In addition, compared with serum creatinine, serum $\mathrm{Cys} \mathrm{C}$ is a more sensitive indicator since earlier increase of serum Cys $\mathrm{C}$ can be detected along with the decrease of glomerular filtration rate. Futhermore, it is related to the hepatic failure mediated renal function changes [4] and thus a valid index for renal function evaluation and prognosis in patients with cirrhosis [5]. In this study, we analyzed the relationship between the Cys $\mathrm{C} / \mathrm{Alb}$ ratio and the liver function in patients with cirrhosis which provides a convenient and efficient way for the evaluation of liver function in patients with cirrhosis.

\section{Methods}

\section{Materials}

The clinical data involves 100 cases of patients with hepatic cirrhosis aged from 29 to $83(60.96 \pm 10.93)$ with 54 male cases and 46 female cases (sex ratio=1.17:1) which was collected between August 2015 and July 2016 from Sichuan Academy of Medical Sciences \& Sichuan Provincial People's Hospital. Among the 100 cases, 36 cases were hepatitis B cirrhosis, 25 cases were alcoholic cirrhosis, 6 cases were hepatitis $\mathrm{B}$ cirrhosis combined with alcoholic cirrhosis, 1 case was hepatitis $\mathrm{C}$ cirrhosis, 8 cases were primary biliary cirrhosis and 24 cases were occult cirrhosis. The following are the inclusion and exclusion criteria.

Inclusion criteria: 1. Patients with hypohepatia, portal hypertension like ascites, gastroscope confirmed esophageal varix, underlying cause of cirrhosis such as viral hepatitis, long-term alcohol consumption and autoimmune liver disease, ultrasound or CT confirmed cirrhosis. 2. Patients with complete medical records. 
Exclusion criteria: 1. Patients without cirrhosis; 2. Patients with both of liver cancer and cirrhosis; 3. Patients with cirrhosis and other cancers; 4. Patients had liver or renal surgical history; 5. Patients with primary renal diseases, hypertension or diabetes; 6 . Patients without complete medical records.

\section{Serum Cys C level detection}

The serum Cys C level was detected by particle-enhanced immunonephelometric assay (Roche Diagnostic, Barcelona, Spain) (Normal serum Cys C $\leq 1.15 \mathrm{mg} / \mathrm{L}$ ).

\section{Liver function evaluation}

The liver function was evaluated according to the Child-Pugh scores [6], as shown in Table 1. In patients with primary biliary cirrhosis (PBC) or primary sclerosing cholangitis (PSC), according to the bilirubin level, the corresponding score is 1 (17-68 umol/L), 2 (68-170 umol/L), 3 (>170 umol/L) respectively.

Table 1. Child-Pugh scoring.

\begin{tabular}{llll}
\hline \multirow{2}{*}{ Items } & \multicolumn{3}{c}{ Score } \\
\cline { 2 - 4 } & 1 & 2 & 3 \\
\hline Hepatic encephalopathy & None & I II & III IV \\
\hline Ascites & None & Mild & Moderate, severe \\
\hline Bilirubin $(\mu \mathrm{mol} / \mathrm{L})$ & $<34$ & $34 \sim 51$ & $>51$ \\
\hline Albumin $(\mathrm{g} / \mathrm{L})$ & $\geq 35$ & $28 \sim 35$ & $\geq 28$ \\
\hline Prothrombin time $(\mathrm{s})$ & $\leq 14$ & $14 \sim 18$ & $\leq 18$
\end{tabular}

Note: The grading is according to the total scores of the 5 items. Grade A: $5-6$, Grade B: 7-9, Grade C: 10-15.

\section{Grouping and relationship analysis}

According to the serum Cys $\mathrm{C}$ level, the patients were divided into two groups: the high $\mathrm{Cys} \mathrm{C}$ level group and the normal
Cys $\mathrm{C}$ level group. The relationship between the Child-Pugh grades/scores and the $\mathrm{Cys} \mathrm{C}$ value or $\mathrm{Cys} \mathrm{C} / \mathrm{Alb}$ ratio were investigated. Analyze the the Cys C/Alb ratio and the ChildPugh scores though linear regression.

\section{Statistical analysis}

SPSS19.0 (SPSS Inc., Chicago, IL, USA) was used for statistical analysis. The relationship between the Cys $\mathrm{C}$ value, Cys C/Alb ratio and the Child-Pugh scores was analyzed by Person correlation. The correlation between the Cys C/Alb ratio and the Child-Pugh scores was determined through linear regression. Receiver operating characteristic (ROC) curve was used to evaluate the accuracy of diagnosis and the significance level was set at $\mathrm{p}<0.05$.

\section{Results}

\section{Child-pugh grading}

Among the 100 cases, 43 cases with increased serum Cys C level (high Cys $\mathrm{C}$ level group) and 57 cases with normal serum Cys $\mathrm{C}$ level (normal Cys $\mathrm{C}$ level group). According to the Child-Pugh grading, there were 4 Child A cases, 19 Child B cases and 20 Child $\mathrm{C}$ cases in the high Cys $\mathrm{C}$ level group. In the normal Cys $\mathrm{C}$ level group, there were 8 Child A cases, 35 Child B cases and 14 Child C cases.

\section{The relationship between the liver function and the Cys C value, Cys C/Alb ratio}

The Cys C value, Cys C/Alb ratio and the related Child-Pugh grades/scores for patients with cirrhosis in two groups are shown in Table 2.

Table 2. The relationship between the Child-Pugh grades/scores and Cys C value, or Cys C/Alb ratio.

\begin{tabular}{|c|c|c|c|c|c|c|}
\hline Items & Child A & Child B & Child C & $\mathbf{R g}$ & Rs & $P$ value \\
\hline \multicolumn{7}{|c|}{ High Cys C level group } \\
\hline$($ Cys C)/(mg/L) & $1.25 \pm 0.11$ & $1.39 \pm 0.17$ & $1.59 \pm 0.26$ & 0.497 & 0.546 & 0.001 \\
\hline (Cys C/Alb)/(× 10-5) & $3.59 \pm 0.33$ & $4.82 \pm 0.62$ & $6.50 \pm 0.59$ & 0.868 & 0.932 & 0 \\
\hline \multicolumn{7}{|c|}{ Normal Cys C level group } \\
\hline (Cys C)/(mg/L) & $0.94 \pm 0.11$ & $0.95 \pm 0.14$ & $0.98 \pm 0.16$ & 0.087 & 0.091 & 0.521 \\
\hline (Cys C/Alb)/(× 10-5) & $2.85 \pm 0.39$ & $3.04 \pm 0.55$ & $3.76 \pm 0.60$ & 0.486 & 0.548 & 0.501 \\
\hline
\end{tabular}




\section{The linear regression relationship between the Cys C/Alb ratio and the child scores}

There is a linear regression relationship between the $\mathrm{Cys} \mathrm{C} / \mathrm{Alb}$ ratio and the Child scores in two groups. Compared with the normal Cys $\mathrm{C}$ level group, the Cys $\mathrm{C} / \mathrm{Alb}$ ratio in the high $\mathrm{Cys}$ $\mathrm{C}$ level group is more closely related to the Child grading (Figure 1).
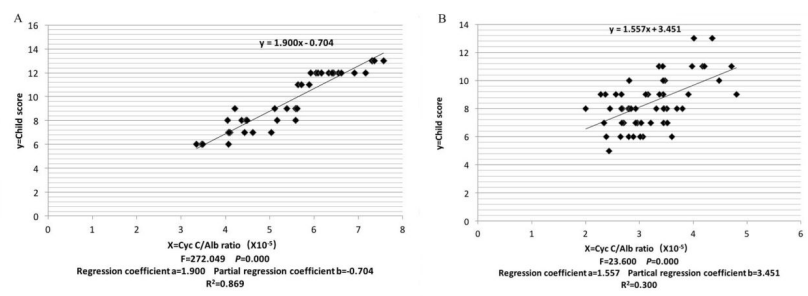

Figure 1. The linear regression relationship between the Cys C/Alb ratio and the Child scores $A$. The linear regression relationship between the Cys C/Alb ratio and Child scores in high Cys $C$ level group.B. The linear regression relationship between the Cys C/Alb ratio and the Child scores in the normal Cys C level group.

\section{The accuracy of liver function evaluation in patients with cirrhosis by serum Cys C/Alb ratio}

As the result shown in Table 3, the sensitivity and specificity of liver function evaluation in patients with cirrhosis by serum Cys $\mathrm{C} / \mathrm{Alb}$ ratio. According to the maximum Youden's index, the optimal critical value of serum Cys C/Alb ratio is $4.072 \times$ $10^{-5}$ for the evaluation of liver function in patients with moderate or severe cirrhosis which exhibits higher sensitivity, specificity and accuracy in the high Cys $\mathrm{C}$ level group. However, ROC analysis doesn't find the critical value of serum
Cys $\mathrm{C} / \mathrm{Alb}$ ratio in the normal Cys $\mathrm{C}$ level group to distinguish patients with moderate or severe cirrhosis (Figure 2).
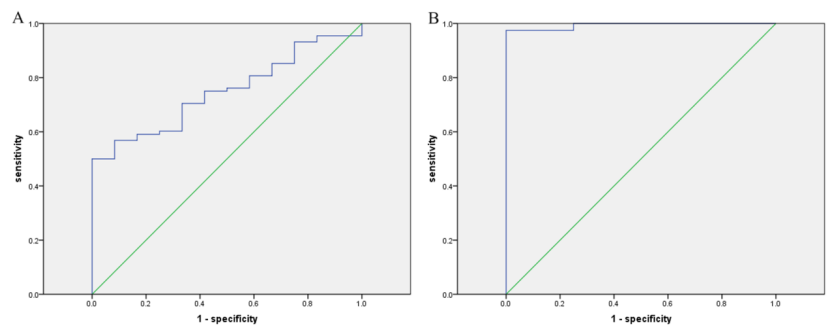

Figure 2. A) The characteristic curve for the evaluation of liver function in patients with moderate or severe cirrhosis (Grade $\geq B$ ) by serum Cys C/Alb ratio. B) The characteristic curve for liver function evaluation in patients with moderate or severe cirrhosis (Grade $\geq B$ ) in the high Cys $C$ level group by serum Cys C/Alb ratio.

\section{Discussion}

The renal function in patients with cirrhosis plays an important role in disease prognosis. However, serum creatinine cannot accurately reflect the glomerular filtration rate due to the cirrhosis-mediated malnutrition and decreased muscle mass $[7,8]$. Instead of serum creatinine, serum Cys $C$ is universally recognized as the indicator for the evaluation of glomerular filtration rate in patients with cirrhosis [9]. Furthermore, serum Cys $\mathrm{C}$ can also reflect the renal function in cirrhosis patients with ascites and normal serum creatinine [10]. Since the content of serum Cys $\mathrm{C}$ is stable and independent of other influences, such as gender, age, muscle mass, drugs and inflammation [11], it reflects the glomerular filtration rate more precisely than serum creatinine [12-15].

Table 3. The sensitivity and specificity of liver function evaluation in patients with cirrhosis by serum Cys C/Alb ratio.

\begin{tabular}{|c|c|c|c|c|c|}
\hline Cirrhosis type and optimal critical value & Sensitivity (\%) & Specificity (\%) & AUC & $95 \%$ confidence interval & Youden's index \\
\hline \multicolumn{6}{|c|}{ Patients with moderate or severe cirrhosis (including normal Cyc $C$ and increased Cys $C$ levels) } \\
\hline Cys C/Alb $\geq 4.072 \times 10^{-5}$ & 50 & 100 & 0.748 & $0.638 \sim 0.858$ & 0.5 \\
\hline \multicolumn{6}{|c|}{ Patients with severe cirrhosis in the high Cys $\mathrm{C}$ level group } \\
\hline Cys C/Alb $\geq 4.072 \times 10^{-5}$ & 97.4 & 100 & 0.994 & $0.974 \sim 1.000$ & 0.974 \\
\hline
\end{tabular}

The serum Cys $\mathrm{C}$ not only reflects the renal function changes in patients with cirrhosis [16,17], but also displays the variation degree of portal hypertension and renal/systemic hemodynamics $[18,19]$. Besides, studies have shown that serum Cys C level is positively direct to the cirrhosis-mediated inflammation and macrophage hypersecretion [20] and increases significantly along with the increase of cathepsin level in chronic liver disease [21]. Therefore, serum Cys C increases with the development of chronic liver disease and is a potential indicator for liver fibrosis [22]. Study has demonstrated that serum Cys $\mathrm{C}$ level could even reflect the degree of liver fibrosis and inflammation in animal chronic liver disease models with normal renal function [23]. In addition, serum Cys $\mathrm{C}$ level is related to prognosis such as the survival rate, mortality rate [24-28]. Chlid-Pugh score is a standard method for the evaluation of liver function in patients with hepatic cirrhosis and mainly includes the index of liver function [6]. With the development of cirrhosis, changes have been occurred in the renal function, liver inflammation and the degree of liver fibrosis. Serum Cys C level is closely related to these changes and thus reflects the degree of hepatic cirrhosis.

The results in this study proved that serum Cys $\mathrm{C}$ value and Cys $\mathrm{C} / \mathrm{Alb}$ ratio are positively related to the Child grades and scores in cirrhosis patients with high serum Cys C levels. On the contrary, in cirrhosis patients with normal serum Cys $\mathrm{C}$ levels, the serum Cys $\mathrm{C}$ value had no relationship with the Child grade and scores, however, the Cys $\mathrm{C} / \mathrm{Alb}$ ratio is 
positively related to the Child grades and scores. Compared with the serum Cys $\mathrm{C}$ value, the $\mathrm{Cys} \mathrm{C} / \mathrm{Alb}$ ratio is better related to the liver function. Besides, there is a linear regression relationship between the $\mathrm{Cys} \mathrm{C} / \mathrm{Alb}$ ratio and the Child scores in both groups. According to the linear regression curve, a closer linear relationship is found between the Cys $\mathrm{C} / \mathrm{Alb}$ ratio and the Child scores in cirrhosis patients with high Cys $\mathrm{C}$ level which reflects the degree of cirrhosis more precisely. The Cys $\mathrm{C}$ value and $\mathrm{Cys} \mathrm{C} / \mathrm{Alb}$ ratio in cirrhosis patients with increased serum $\mathrm{Cys} \mathrm{C}$ level can better reflect the degree of cirrhosis and the Cys $\mathrm{C} / \mathrm{Alb}$ ratio is more closely related to the liver function. In addition, it is more precise to evaluate the liver function in patients with moderate or severe cirrhosis (Grade $\geq \mathrm{B}$ ) with the critical value of serum Cys $\mathrm{C} / \mathrm{Alb}$ ratio $\geq 4.072 \times 10^{-5}$, however, this critical value still plays a certain role in the evaluation of liver function in cirrhosis patients with normal serum Cys $\mathrm{C}$ level.

\section{References}

1. Schuppan D, Afdhal NH. Liver cirrhosis. Lancet 2008; 371: 838-851.

2. Arias IM, Pobes A, Baños M. [Cystatin C. New marker of renal function]. Nefrologia 2005; 25: 217-220.

3. Cholongitas E, Shusang V, Marelli L, Nair D, Thomas M, Patch D, Burns A, Sweny P, Burroughs AK. Renal function assessment in cirrhosis-difficulties and alternative measurements. Aliment Pharmacol Ther 2007; 26: 969-978.

4. Ustundag Y, Samsar U, Acikgoz S, Cabuk M, Kiran S, Kulah E, Aydemir S. Analysis of glomerular filtration rate, serum cystatin $\mathrm{C}$ levels, and renal resistive index values in cirrhosis patients. Clin Chem Lab Med 2007; 45: 890-894.

5. Adachi M, Tanaka A, Aiso M, Takamori Y, Takikawa H. Benefit of cystatin $\mathrm{C}$ in evaluation of renal function and prediction of survival in patients with cirrhosis. Hepatol Res 2015; 45: 1299-1306.

6. Cholongitas E, Papatheodoridis G V, Vangeli M, Terreni N, Patch D, Burroughs AK. Systematic review: the model for end-stage liver disease-should it replace Child-Pugh's classification for assessing prognosis in cirrhosis? Aliment Pharmacol Ther 2005; 22: 1079-1089.

7. Demirtas S, Bozbas A, Akbay A, Yavuz Y, Karaca L. Diagnostic value of serum cystatin $\mathrm{C}$ for evaluation of hepatorenal syndrome. Clin Chim Acta 2001; 311: 81-89.

8. Teneva BH. Pathogenesis and assessment of renal function in patients with liver cirrhosis. Folia Med (Plovdiv) 2012; 54: 5-13.

9. Pöge U, Gerhardt T, Stoffel-Wagner B, Klehr HU, Sauerbruch T, Woitas RP. Calculation of glomerular filtration rate based on cystatin $\mathrm{C}$ in cirrhotic patients. Nephrol Dial Transplant 2005; 21: 660-664.

10. Kim DJ, Kang HS, Choi HS, Cho HJ, Kim ES, Keum B, An H, Kim JH, Seo YS, Kim YS. Serum cystatin C level is a useful marker for the evaluation of renal function in patients with cirrhotic ascites and normal serum creatinine levels. Korean J Hepatol 2011; 17: 130.
11. Weinert LS, Camargo EG, Soares AA, Silveiro SP. Glomerular filtration rate estimation: performance of serum cystatin C-based prediction equations. Clin Chem Lab Med 2011; 49: 1761-1771.

12. Francoz C, Glotz D, Moreau R, Durand F. The evaluation of renal function and disease in patients with cirrhosis. $\mathrm{J}$ Hepatol 2010; 52: 605-613.

13. Torre A, Aguirre-Valadez JM, Arreola-Guerra JM, GarcíaFlores OR, García-Juárez I, Cruz-Rivera C, Correa-Rotter $\mathrm{R}$, Niño-Cruz JA. Creatinine versus cystatin $\mathrm{c}$ for estimating GFR in patients with liver cirrhosis. Am J Kidney Dis 2016; 67: 342-344.

14. Beben T, Rifkin DE. GFR estimating equations and liver disease. Adv Chronic Kidney Dis 2015; 22: 337-342.

15. Wang D, Feng J-F, Wang A-Q, Yang Y-W, Liu Y-S. Role of Cystatin $\mathrm{C}$ and glomerular filtration rate in diagnosis of kidney impairment in hepatic cirrhosis patients. Medicine (Baltimore) 2017.

16. Gerbes AL, Gülberg V, Bilzer M, Vogeser M. Evaluation of serum cystatin $\mathrm{C}$ concentration as a marker of renal function in patients with cirrhosis of the liver. Gut BMJ 2002; 50: 106-110.

17. Omar M, Abdel-Razek W, Abo-Raia G, Assem M, El-Azab G. Evaluation of serum cystatin $\mathrm{C}$ as a marker of early renal impairment in patients with liver cirrhosis. Int $\mathrm{J}$ Hepatol 2015.

18. Mindikoglu AL, Dowling TC, Wong-You-Cheong JJ, Christenson RH, Magder LS, Hutson WR, Seliger SL, Weir MR. A pilot study to evaluate renal hemodynamics in cirrhosis by simultaneous glomerular filtration rate, renal plasma flow, renal resistive indices and biomarkers measurements. Am J Nephrol 2014; 39: 543-552.

19. Hurry PK, Poulsen JH, Bendtsen F, Møller S. Neutrophil gelatinase-associated lipocalin and cystatin $\mathrm{C}$ in cirrhosis and portal hypertension: Relations to organ extraction and dysfunction. J Gastroenterol Hepatol 2017; 32: 473-481.

20. Korolenko TA, Filatova TG, Iuz'ko I, Savchenko NG, Voloshina NB, Goncharova NV. [Cystatin C: a biological role and impaired secretion in viral hepatitis $\mathrm{c}$ and hepatic cirrhosis]. Klin Lab Diagn 2007; 12: 18-20.

21. Chu SC, Wang CP, Chang YH, Hsieh YS, Yang SF, Su JM, Yang CC, Chiou HL. Increased cystatin C serum concentrations in patients with hepatic diseases of various severities. Clin Chim Acta 2004; 341: 133-138.

22. Takeuchi M, Fukuda Y, Nakano I, Katano Y, Hayakawa T. Elevation of serum cystatin $\mathrm{C}$ concentrations in patients with chronic liver disease. Eur J Gastroenterol Hepatol 2001; 13: 951-955.

23. Ladero JM, Cárdenas MC, Ortega L, González-Pino A, Cuenca F, Morales C, Lee-Brunner A. Serum cystatin C: a non-invasive marker of liver fibrosis or of current liver fibrogenesis in chronic hepatitis C? Ann Hepatol 2012; 11: 648-651.

24. Seo YS, Jung ES, An H, Kim JH, Jung YK, Kim JH, Yim HJ, Yeon JE, Byun KS, Kim CD. Serum cystatin C level is a good prognostic marker in patients with cirrhotic ascites 
and normal serum creatinine levels. Liver Int 2009; 29: 1521-1527.

25. Chung MY, Jun DW, Sung SA. Diagnostic value of cystatin $\mathrm{C}$ for predicting acute kidney injury in patients with liver cirrhosis. Korean J Hepatol 2010; 16: 301.

26. Sharawey MA, Shawky EM, Ali LH, Mohammed AA, Hassan HA, Fouad YM. Cystatin C: a predictor of hepatorenal syndrome in patients with liver cirrhosis. Hepatol Int 2011; 5: 927-933.

27. Ahn HS, Kim YS, Kim SG, Kim HK, Min SK, Jeong SW, Jang JY, Lee SH, Kim HS, Kim BS. Cystatin C is a good predictor of hepatorenal syndrome and survival in patients with cirrhosis who have normal serum creatinine levels. Hepatogastroenterology 2012; 59: 1168-1173.
28. Belcher JM, Sanyal AJ, Garcia-Tsao G, Ansari N, Coca SG, Shlipak MG, Parikh CR. Early trends in cystatin C and outcomes in patients with cirrhosis and acute kidney injury. Int J Nephrol 2014.

\section{*Correspondence to}

Yang Xue

Department of Gastroenterology

Sichuan Academy of Medical Sciences and Sichuan Provincial People's Hospital

PR China 